\title{
Article \\ Carbon Sequestration Potential of Agroforestry Systems in Degraded Landscapes in West Java, Indonesia
}

\author{
Mohamad Siarudin ${ }^{1}$ D, Syed Ajijur Rahman ${ }^{2, *(D)}$, Yustina Artati ${ }^{3, *}$, Yonky Indrajaya ${ }^{4} \mathbb{D}$, Sari Narulita $^{3}$, \\ Muhammad Juan Ardha ${ }^{5}$ and Markku Larjavaara ${ }^{2, *}$
}

1 Agroforestry Research and Development Center (ARDC), Ministry of Environment and Forestry, Jalan Raya Ciamis-Banjar Km 4, Ciamis 46201, Indonesia; msiarudin@yahoo.com

2 Institute of Ecology and Key Laboratory for Earth Surface Processes of the Ministry of Education, College of Urban and Environmental Science, Peking University, Beijing 100871, China

3 Center for International Forestry Research (CIFOR), Bogor 16115, Indonesia; s.narulita@cgiar.org

4 Watershed Management Technology Center (WMTC), Ministry of Environment and Forestry, Surakarta 57169, Indonesia; yonky_indrajaya@yahoo.com

5 Forest Carbon, Jakarta 10210, Indonesia; j.ardha@forestcarbon.com

* Correspondence: sumonsociology@yahoo.com (S.A.R.); y.artati@cgiar.org (Y.A.); markku.larjavaara@gmail.com (M.L.)

Citation: Siarudin, M.; Rahman, S.A. Artati, Y.; Indrajaya, Y.; Narulita, S.; Ardha, M.J.; Larjavaara, M. Carbon Sequestration Potential of Agroforestry Systems in Degraded Landscapes in West Java, Indonesia. Forests 2021, 12, 714. https://doi.org/ $10.3390 /$ f12060714

Academic Editor: Julien Fortier

Received: 25 March 2021

Accepted: 26 May 2021

Published: 31 May 2021

Publisher's Note: MDPI stays neutral with regard to jurisdictional claims in published maps and institutional affiliations.

Copyright: (c) 2021 by the authors. Licensee MDPI, Basel, Switzerland. This article is an open access article distributed under the terms and conditions of the Creative Commons Attribution (CC BY) license (https:/ / creativecommons.org/licenses/by/ $4.0 /)$.

\begin{abstract}
When restoring degraded landscapes, approaches capable of striking a balance between improving environmental services and enhancing human wellbeing need to be considered. Agroforestry is an important option for restoring degraded land and associated ecosystem functions. Using survey, key informant interview and rapid carbon stock appraisal (RaCSA) methods, this study was conducted in five districts in West Java province to examine potential carbon stock in agroforestry systems practiced by smallholder farmers on degraded landscapes. Six agroforestry systems with differing carbon stocks were identified: gmelina (Gmelina arborea Roxb.) + cardamom (Amomum compactum); manglid (Magnolia champaca (L.) Baill. ex Pierre) + cardamom; caddam (Neolamarckiacadamba (Roxb.) Bosser) + cardamom; caddam + elephant grass (Pennisetum purpureum Schumach.); mixed-tree + fishpond; and mixed-tree lots. Compared to other systems, mixed-tree lots had the highest carbon stock at $108.9 \mathrm{Mg} \mathrm{ha}^{-1}$. Carbon stock variations related to species density and diversity. Farmers from research sites said these systems also prevent soil erosion and help to restore degraded land. Farmers' adoption of agroforestry can be enhanced by the implementation of supportive policies and measures, backed by scientific research.
\end{abstract}

Keywords: agroforestry; land restoration; carbon sequestration; smallholder farmers; system adoption

\section{Introduction}

Land degradation often causes severe environmental and socioeconomic problems [1]. It leads to declining environmental services, such as biodiversity, climate regulation, water supply, carbon stock, and other services [2]. Degradation also causes decreased land productivity, with serious cascading effects for human wellbeing, e.g., poverty, malnutrition, disease, forced migration, cultural damage, and even war [3]. Indonesia has approximately 14 million hectares (ha) of degraded land providing limited benefits for humans and nature [4]. Causes of land degradation can be categorized into direct and indirect ones. Direct causes in Indonesia include agricultural land expansion, overgrazing, commercial logging, and urbanization [5]. Indirect causes are typically population pressures coupled with poverty, as people often have to convert forests for agricultural land use to meet food demands beyond the capacity of existing farmlands [6]. The exploitation of forests to meet increasing demands for timber, fuel wood, and other products associated with population growth can also lead to land degradation [7]. Land degradation also increases emissions of greenhouse gases (GHGs) into the atmosphere, thereby contributing to climate change. 
Indonesia is the world's third largest emitter of GHGs, with land-use change contributing most of its emissions [8]. The country has committed to unconditional and conditional emissions reductions of $29 \%$ and $41 \%$ respectively by 2030 , as part of the global climate action following the Paris Agreement in 2015 [9]. Promoting climate resilience in food, water, and energy is the main pathway for the country's efforts to mitigate climate change. This includes the restoration of 12 million ha of degraded land by 2030 for landscape resilience $[9,10]$.

The forest landscape restoration (FLR) approach is gaining interest for the restoration of degraded land. It is a comprehensive approach aimed at improving ecological functions and enhancing human wellbeing [11]. Agroforestry can be an important FLR approach with the potential to restore degraded land by reestablishing ecological processes, structures and ecosystem functions, while also enabling economic returns and the maintenance of livelihoods, local knowledge, and culture [12]. Agroforestry-based restoration projects across the tropics have been documented vividly by a number of scientific studies from Brazil to Mozambique and Indonesia [13-17].

By diversifying and enhancing farm products and services, agroforestry systems can meet the financial and social objectives crucial for local communities $[18,19]$. As an alternative source of important forest products, such as timber, fuelwood, fruits, and vegetables, agroforestry can reduce encroachment on local forests [20-22]. It can also improve soil fertility by enhancing nutrients, conserving soil moisture, protecting soil from erosion, moderating microclimates, sequestrating carbon, and diversifying habitats for wildlife and humans [23-26].

People across the Indonesian archipelago practice various agroforestry systems for their livelihood needs. These include spice and nut agroforests in the Moluccas; sugar palm and salak agroforests in Bali and Lombok; illipe-nut forests (tembawang) in West Kalimantan; benzoin gardens in North Sumatra; fruit and timber agroforests in Maninjau, West Sumatra; damar agroforests in Pesisir, Lampung; and fruit agroforests in Jambi and Palembang [21]. Notable examples of farmers managing to restore degraded landscapes are the planting of damar (Agathis dammara (Lamb.) Rich.) trees in degraded swidden areas in Jambi, Sumatra, and tamanu (Calophyllum inophyllum L.) trees on barren land in Wonogiri, Central Java $[27,28]$. Other studies provide evidence of agroforestry systems delivering carbon stock and sequestration $[29,30]$. The ability of agroforestry to store carbon varies from $37.7 \mathrm{Mg} \mathrm{ha}^{-1}$ at 1-10 years and $72.6 \mathrm{Mg} \mathrm{ha}^{-1}$ at 11-30 years [31]. A study of a 30-year-old home garden system in Lampung, Indonesia indicated above-ground biomass of $35.3 \mathrm{MgC} \mathrm{ha}^{-1}$ [32]. In Indonesia's Bengkulu province, mixed tree agroforestry systems store around 95.2 tons ha ${ }^{-1}$ regardless of age [33]. Carbon stock storage in agroforestry systems with a combination of oil palm and agar wood vary between 78.28 and $79.13 \mathrm{Mg} \mathrm{C} \mathrm{ha}^{-1}$ in regard to different levels of soil bulk density [34]. While simple and complex agroforestry systems adjacent to the Lore Lindu National Park buffer zones in Palu, Indonesia show significant differences in carbon stock. Simple agroforestry systems (combining individual trees and cash crops) store an average $37.30 \mathrm{Mg} \mathrm{C} \mathrm{ha}^{-1}$ ranging from $30.32-45.05 \mathrm{MgC} \mathrm{ha}^{-1}$, while complex agroforestry systems (combining multiple tree species, shrubs, bushes, and crops) store an average $80.05 \mathrm{Mg} \mathrm{C} \mathrm{ha}^{-1}$ of carbon stock ranging from 71.99-85.45 $\mathrm{Mg} \mathrm{C} \mathrm{ha}^{-1}$ [35]. As agroforestry systems are crucial for local people and nature, to corroborate agroforestry knowledge, the specific objective of this paper is to reinvestigate the type, component, management, and carbon sequestration potential of six common agroforestry systems, practiced by local communities in degraded landscapes in five administrative regions in West Java province. Although there are various definitions of agroforestry, we have defined it as a land-use system where woody perennials are used deliberately in the same land management units as other agricultural crops and/or animals, in some form of spatial arrangement or temporal sequence. We have hypothesized that mixed tree-based agroforestry systems have high carbon sequestration potential as they consist of various trees with understory. 


\section{Materials and Methods}

\subsection{Study Sites}

Five districts in West Java province, i.e., Banjar, Ciamis, Garut, Tasikmalaya, and Pangandaran were selected as study areas (see Figure 1). These districts were selected as they represent $21 \%$ of all degraded land in West Java province (West Java province has the largest area of degraded land among all provinces in Java, i.e., 900,000 ha [4]) (see Table 1), and because prior information showed local farmers practicing various agroforestry systems on degraded land, allowing investigations of system types and their carbon sequestration potential. Conditions in these study areas can also be representative of many other parts of Indonesian and tropical Asian agricultural landscapes in general.

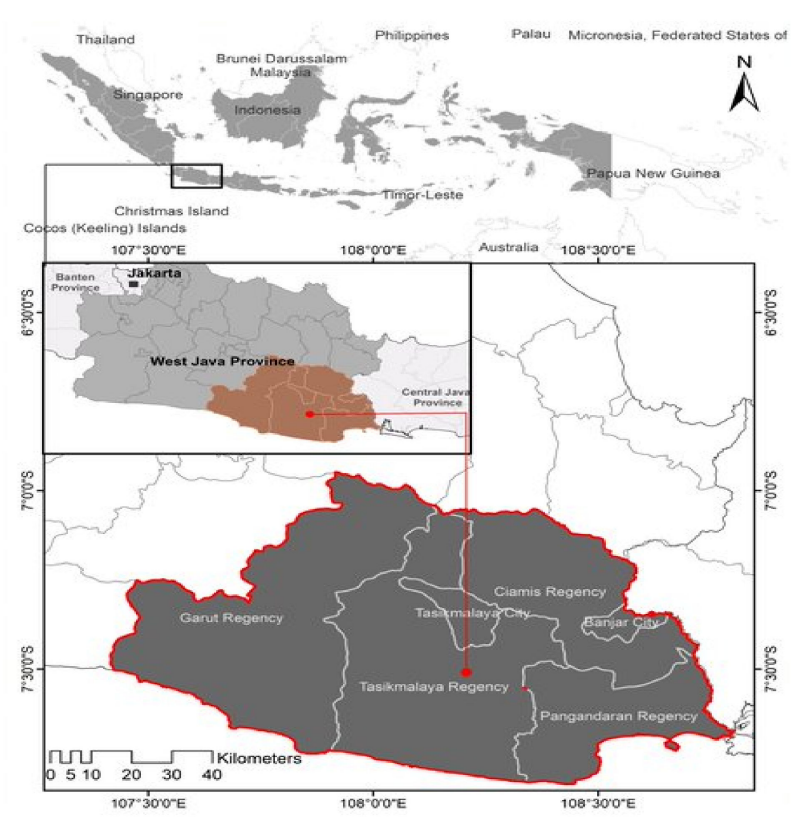

(a)

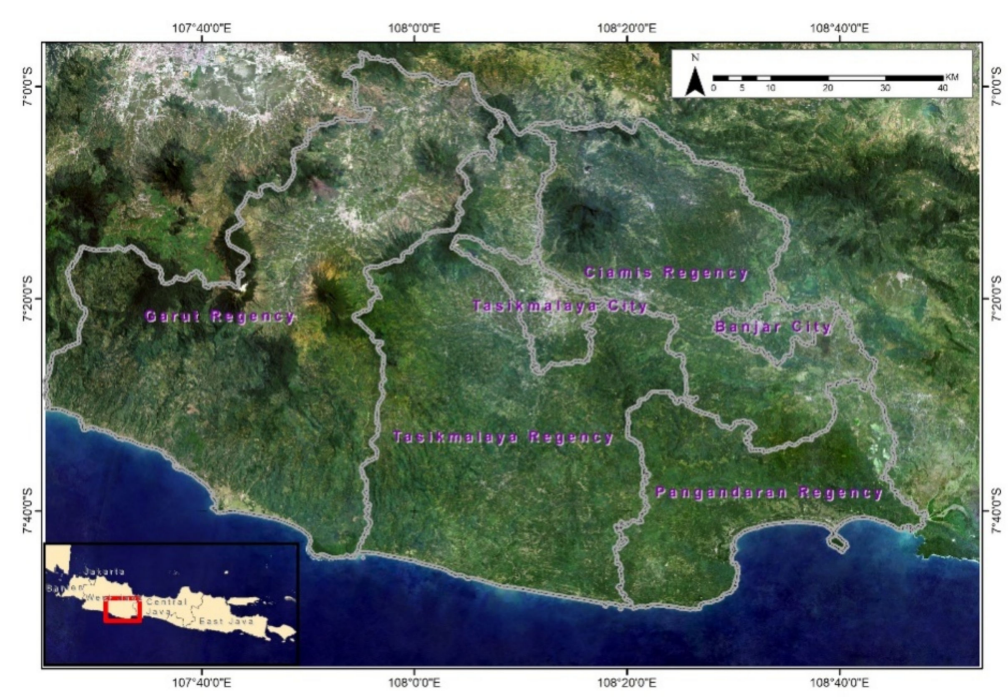

(b)

Figure 1. Locations of study sites in West Java (a), Landsat 8 imagery (2020) of study sites (b).

The five districts had a total area of $8850 \mathrm{~km}^{2}$ and a human population of $6,198,824$ in 2020, and therefore a high population density of 700 inhabitants per $\mathrm{km}^{2}$ [36]. The climate is equatorial with two distinct seasons: dry from April to October, and rainy from 
November to March. Average daily minimum air humidity varies from $50 \%-89 \%$ (see Table 1). Soils are dominated by volcanic sedimentary rocks and are highly fertile. Given the proximity of standing volcanoes, the area is considered highly seismic.

Table 1. Basic characteristics of the research sites.

\begin{tabular}{|c|c|c|c|c|c|c|}
\hline District & Location & $\begin{array}{c}\text { Average } \\
\text { Temperature }\left({ }^{\circ} \mathrm{C}\right)\end{array}$ & $\begin{array}{c}\text { Average } \\
\text { Rainfall (mm) }\end{array}$ & Humidity (\%) & Elevation (m) & $\begin{array}{c}\text { Total Land Area } \\
\text { (ha)/Total } \\
\text { Degraded Land } \\
\text { Area (ha) }\end{array}$ \\
\hline Banjar & $7.37^{\circ} \mathrm{S} 108.53^{\circ} \mathrm{E}$ & 28.5 & 1600 & $69-85$ & $31-79$ & $13,195 / 620(4.70 \%)$ \\
\hline Ciamis & $6.75^{\circ} \mathrm{S} 108.38^{\circ} \mathrm{E}$ & 27 & 2800 & $68-87$ & $31-768$ & $\begin{array}{c}159,763 / 24,259 \\
(15.19 \%)\end{array}$ \\
\hline Garut & $7.22^{\circ} \mathrm{S} 107.9^{\circ} \mathrm{E}$ & 25.5 & 3294 & $73-85$ & $100-1500$ & $\begin{array}{c}309,601 / 96,730 \\
(31.24 \%)\end{array}$ \\
\hline Tasikmalaya & $7.33^{\circ} \mathrm{S} 108.2^{\circ} \mathrm{E}$ & 26 & 2171 & $50-73$ & 0-2000 & $\begin{array}{c}289,203 / 61,110 \\
(21.13 \%)\end{array}$ \\
\hline Pangandaran & $7.54^{\circ} \mathrm{S} 108.50^{\circ} \mathrm{E}$ & 26.5 & 2750 & $85-89$ & $0-2500$ & $\begin{array}{c}112,765 / 13,167 \\
(11.68 \%)\end{array}$ \\
\hline
\end{tabular}

Source: Badan Pusat Statistik [37].

Agriculture plays an important role in district economies, and contributes $43 \%$ of total income in Tasikmalaya [38]. Agriculture also dominates land use in Banjar district, covering $75 \%$ of the district's total land area [39]. These districts are also important providers of agricultural products to other areas in West Java. Garut, for example, is a major source of food for Bandung, the provincial capital of West Java, which is around 68 $\mathrm{km}$ away. These districts also provide important ecosystem services to other areas in West Java. Mountainous areas in Garut, Pangandaran, and Tasikmalaya are home to sources of important watersheds in the province. The highlands of Pangandaran district, for example, have three major rivers: the Cijulang, Citanduy, and Cimedang, which support water supplies, climate regulation, and aesthetics for lowland areas [40].

\subsection{Data Collection and Analysis}

This study combined quantitative and qualitative approaches, applying field surveys and interviews with key informants. Four farmer group heads, two forestry extension officers, and twenty landowners were selected purposively based on their experience in agroforestry and other land-use systems to obtain a general overview of major agroforestry practices in the study sites. Based on the field surveys and interviews, 50 plots (18 plots for the manglid-based system, 17 for the gmelina-based system, 6 for the caddam-based system, 3 for the sylvofishery system, and 6 for the mixed-tree lot system) from five districts were chosen purposively and observed to secure data on stand structure and composition. Primary data was collected during surveys by taking measurements directly in the field. The data collected covered the diameter at breast height (D) of trees using diameter tapes, tree height using digital dendrometers, tree species with local farmers identifying local names for expert translation to scientific names, and numbers of individual trees. Interviews were held with four key informants to secure qualitative information on socio-economic importance and management level, including product uses, economic purposes of product use (commercial, semi-commercial, subsistence), financial investment, and labor intensity. The data was analyzed comparatively between the identified systems. The agroforestry systems identified in the study locations were classified based on structure, function, socio-economic importance, and management level [41].

Carbon stock (C)estimation data was based on previous publications, i.e., Indrajaya et al. [29], Siarudin and Indrajaya [42,43], and Siarudin [44] with additional data measurements at the same research locations. The RaCSA (Rapid Carbon Stock Appraisal) method developed by Hairiah et al. [45] was used in this study to estimate C stocks in aboveground biomass (AGB). RACSA can reduce time and expense, and is considered more 
effective $[46,47]$. Several previous studies have used this method to estimate carbon stock in agroforestry systems $[46,48]$. The components measured were tree biomass, understory biomass, woody necromass, and non-woody necromass (litter). Within $10 \mathrm{~m} \times 20 \mathrm{~m}$ or $5 \mathrm{~m} \times 40 \mathrm{~m}$ plots, tree biomass measurements were collected in diameter at breast height $(5-30 \mathrm{~cm})$, and tree-height specifically for Arecaceae (palms). If trees with $\mathrm{D}$ greater than $30 \mathrm{~cm}$ were present in a plot, the main plot width was expanded to $20 \mathrm{~m} \times 100 \mathrm{~m}$ to measure trees with $\mathrm{D}$ greater than $30 \mathrm{~cm}$. The weight estimation of above-ground biomass of each tree was measured using the generic allometric equation for biomass calculations by Chave et al. [49].

$$
A G B=\rho \times\left(-1.499+2.148 \ln (D)+0.207\left(\ln (D)^{2}\right)-0.028\left(\ln (D)^{3}\right)\right)
$$

where $A G B$ represents the weight of above-ground biomass ( $\mathrm{kg}), \rho$ is wood density, and $D$ is the diameter at breast height $(\mathrm{cm})$. The generic allometric equation used in this study [49] is suggested by Hairiah et al. [45] to estimate the weight of aboveground biomass. Research conducted by Hairiah et al. [45] shows that the generic equation suggested by Chave et al. [49] is valid in Indonesia, especially if diameter (D) is less than $30 \mathrm{~cm}$. The generic allometric Chave equation has been applied to estimate $C$ stocks in various forest types in the Gunung Halimun National Park (GHSNP), West Java, Indonesia [50]. However, as the local allometric equation for the caddam species in our research area is available [51], we used this local equation to get a more accurate estimation, specifically for the caddambased agroforestry system, i.e.,

$$
A G B=0.014 D^{2.958}
$$

The wood density value of each tree species refers to the Global Wood Density Database [52]. The content is assumed to be 0.47 of the biomass weight [53]. Measurements of woody necromass were collected in the same plots as tree measurements. These included standing dead trees, stumps of felled trees/fallen trees, or fallen dead tree trunks. Using RaCSA procedures for measuring necromass from Hairiah et al. [45], diameters of 5-30 cm were measured in plots of $5 \mathrm{~m} \times 40 \mathrm{~m}$ or $10 \mathrm{~m} \times 20 \mathrm{~m}$, while necromasses with diameters of more than $30 \mathrm{~cm}$ were measured in $20 \mathrm{~m} \times 100 \mathrm{~m}$ plots. The data measured covered volume and degree of decay. Total dry (biomass) weight was estimated by using wood density secondary data, volume and degree of decay. The degree of decay was measured subjectively in the field based on the degree of biomass intactness from decay, ranging from $50 \%$ (for half decayed) to $100 \%$ (undecayed) [45].

Data on understory biomass and non-woody necromass (litter) was collected by gathering biomass samples in plots of $0.5 \mathrm{~m} \times 0.5 \mathrm{~m}$. Fresh weight was measured, and 100 to $300 \mathrm{~g}$ samples were taken to measure sample dry weight and extrapolate total dry weight estimations. These data were analyzed descriptively. We have also analyzed the relations between the $\mathrm{D}$, stand density and tree basal area (BA) to the C-stock using a simple linear regression.

\section{Results}

\subsection{System Characteristics}

In the study sites in West Java, agroforestry systems practiced by local farmers appear in several sub systems: intercropping combining trees and crops, trees and pasture, trees and aquaculture, and multipurpose tree lots (see Table 2 and Figure 2). Trees in the observed systems are fast-growing commercial species, i.e., manglid, gmelina, and caddam. Farmers sell timber from these species mainly to wood processing industries for veneer, plywood, furniture, and woodworking. Cardamom is the most popular crop for cultivation in the understory of these tree-based systems. 
Table 2. Description of common agroforestry systems across the study sites in West Java.

\begin{tabular}{|c|c|c|c|c|c|}
\hline System & $\begin{array}{c}\text { Major } \\
\text { Component }\end{array}$ & Species & Structure & Products & $\begin{array}{c}\text { Uses and } \\
\text { Management Level }\end{array}$ \\
\hline \multirow{3}{*}{ Agri silviculture } & \multirow{3}{*}{ Trees + crops } & $\begin{array}{l}\text { Manglid + cardamom } \\
\text { (Amomum compactum) }\end{array}$ & $\begin{array}{l}\text { Regular spacing (initial } \\
\text { tree spacing } 4 \mathrm{~m} \times 2 \mathrm{~m} \\
\quad \text { or } 2 \mathrm{~m} \times 2 \mathrm{~m} \text { ) }\end{array}$ & $\begin{array}{c}\text { Timber (Manglid), } \\
\text { food and } \\
\text { medicine (cardamom) }\end{array}$ & $\begin{array}{l}\text { Commercial. } \\
\text { Medium-high input }\end{array}$ \\
\hline & & $\begin{array}{l}\text { Gmelina + cardamom } \\
\text { (Amomum compactum) }\end{array}$ & $\begin{array}{l}\text { Regular spacing (initial } \\
\text { tree spacing } 2 \mathrm{~m} \times 2 \mathrm{~m} \\
\quad \text { or } 2 \mathrm{~m} \times 1 \mathrm{~m} \text { ) }\end{array}$ & $\begin{array}{c}\text { Timber (Gmelina), } \\
\text { food, and } \\
\text { medicine (cardamom) }\end{array}$ & $\begin{array}{l}\text { Commercial. } \\
\text { Medium-high input }\end{array}$ \\
\hline & & $\begin{array}{l}\text { Caddam + Cardamom } \\
\text { (Amomum compactum) }\end{array}$ & $\begin{array}{l}\text { Regular spacing (initial } \\
\text { tree spacing } 4 \mathrm{~m} \times 2 \mathrm{~m} \text { ) }\end{array}$ & $\begin{array}{c}\text { Timber (Caddam), } \\
\text { food and } \\
\text { medicine (cardamom) }\end{array}$ & $\begin{array}{c}\text { Commercial. } \\
\text { Medium-high input }\end{array}$ \\
\hline Silvopasture & Trees + pastures & $\begin{array}{c}\text { Caddam + elephant } \\
\text { grass (Pennisetum } \\
\text { purpureum) }\end{array}$ & $\begin{array}{l}\text { Regular spacing (initial } \\
\text { tree spacing } 4 \mathrm{~m} \times 2 \mathrm{~m} \text { ) }\end{array}$ & $\begin{array}{c}\text { Timber (Caddam), } \\
\text { fodder (elephant grass) }\end{array}$ & $\begin{array}{c}\text { Commercial, } \\
\text { subsistence. } \\
\text { Medium-high input }\end{array}$ \\
\hline Silvofishery & $\begin{array}{c}\text { Trees }+ \text { freshwater } \\
\text { fishpond }\end{array}$ & Various trees + fish & $\begin{array}{l}\text { Irregular spacing, trees } \\
\text { along the embankment }\end{array}$ & $\begin{array}{l}\text { Timber (trees), food } \\
\text { (fish, fruits), soil } \\
\text { conservation (trees) }\end{array}$ & $\begin{array}{c}\text { Commercial, } \\
\text { subsistence. } \\
\text { Medium-high input }\end{array}$ \\
\hline Mixed-tree lots & $\begin{array}{l}\text { Trees + natural } \\
\text { undergrowth }\end{array}$ & Various trees + weed & Irregular spacing & $\begin{array}{l}\text { Timber (trees), } \\
\text { food (fruits), } \\
\text { fuelwood (trees) }\end{array}$ & $\begin{array}{l}\text { Subsistence, } \\
\text { semi-commercial. } \\
\text { Low input }\end{array}$ \\
\hline
\end{tabular}

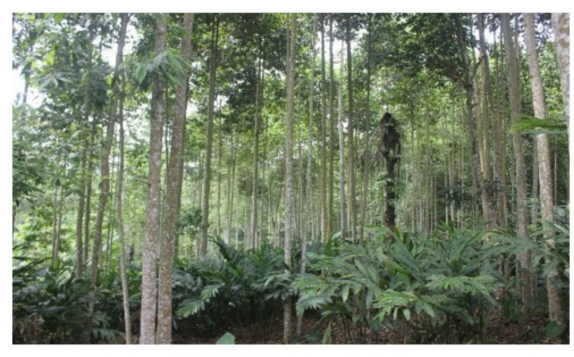

Manglid + cardamom

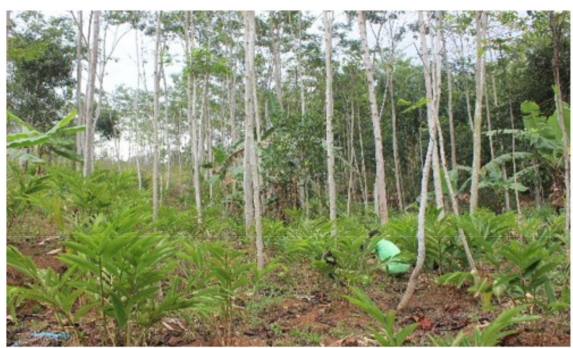

Caddam + cardamom

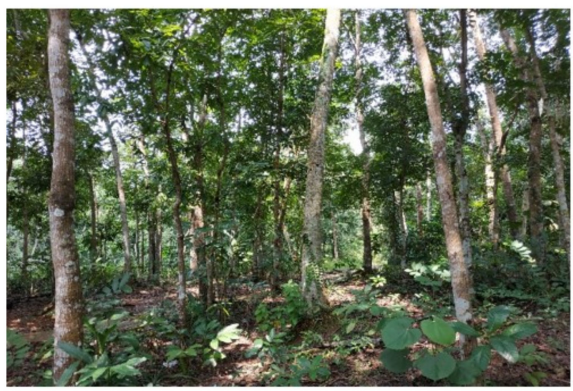

Mixed-tree lots

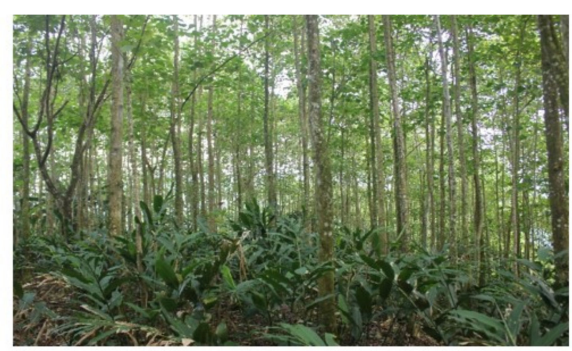

Gmelina + cardamom

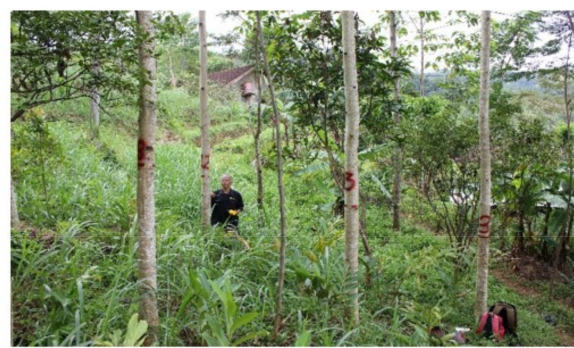

Caddam + elephant grass

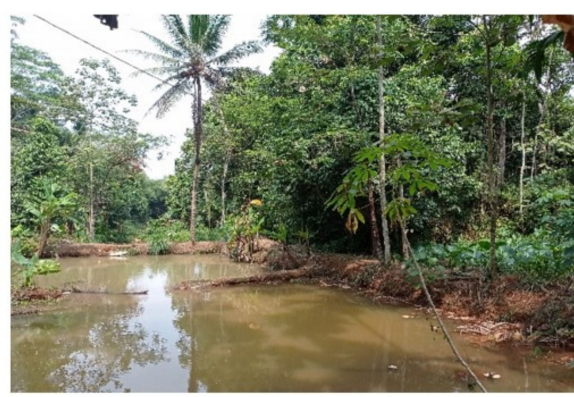

Trees + fishponds

Figure 2. Common agroforestry systems in the study sites in West Java.

Some farmers in the study sites apply complex agroforestry cropping systems with mixed-tree species. Generally, they do not follow any specific spacing patterns in such systems, and allocate less space for understory crops. As a result, stands in such systems 
take the form of uneven-aged multispecies tree lots. Species found in these systems include teak (Tectona grandis Linn. F.), durian (Durio zibethinus Murr.), mahogany (Swietenia sp.), langsat (Lansium domesticum Corr.), large leaf rose mallow (Hibiscus macrophyllus Roxb. ex Hornem.), dog fruit (Archidendron pauciflorum (Benth.) I.C. Nielsen), coconut (Cocos nucifera L.), rambutan (Nephelium lappaceum L.), jackfruit (Artocarpus heterophyllus Lam.), and bitter bean (Parkia speciosa Hassk.). Such trees are also present in silvofishery systems where farmers breed various freshwater fish species in fishponds. In both mixed-tree lot and silvofishery systems, farmers allow trees to grow without intensive maintenance, relying on natural regeneration or planting a few species in any spaces. Based on observations and information from key informants, the above systems practiced by farmers in study sites help prevent landslides, topsoil erosion, and restore land through the regeneration of trees on the land which is already degraded.

The agroforestry systems studied in the study sites are often temporal in nature. Manglid has been planted in the eastern part of West Java province since the late 1980s, and the species persists on private forest land to this day through several rotations. Gmelina and caddam trees were planted more recently, around the early 2000s, and are now partially harvested. Based on observations in Ciamis and Garut districts, some farmers apply clear cutting, while others practice selective cutting. Some farmers maintain the same species either by replanting or relying on natural regeneration.

Farmers commonly apply selective cutting in mixed tree lot systems. They harvest trees that have reached diameters agreed with traders and leave others to continue growing. However, some landowners apply clear-cutting, mainly when they want to cultivate new tree species. Meanwhile, tree species composition in silvofishery systems is generally longer lasting as they generally comprise multipurpose tree species that do not require cutting within a certain period.

Seasonal crops (e.g., cardamom, elephant grass) are planted while trees are still young. Farmers carry out maintenance in the form of regular weeding and fertilizing, depending on their capacity to provide financial capital and labor. The understory is often damaged during tree harvesting, which provides an opportune moment for farmers to regenerate after planting the next rotation of trees. In mixed tree lot systems, farmers do not plant specific understory crops, as the ground is most commonly covered by weeds, thus requiring less input in its management than gmelina- and caddam-based agroforestry systems, which involve intensive crop cultivation.

\subsection{Carbon Stock}

C stock in agroforestry systems in the West Java study sites varied from $37-108.6 \mathrm{Mg} \mathrm{ha}^{-1}$ (see Table 3). The trees in each system comprise the majority of carbon stock in comparison to understory and necromass. Manglid- and caddam-based agroforestry systems in Garut and Tasikmalaya have $37 \mathrm{Mg} \mathrm{ha}^{-1}$ and $44 \mathrm{Mg} \mathrm{ha}^{-1}$ of C stock respectively, due to their maintaining regular tree density to support understory species growth. Silvofishery systems in Ciamis show the lowest basal area of trees (i.e., $12.9 \mathrm{~m}^{2} \mathrm{ha}^{-1}$ ), due to the spatial arrangements of such systems providing dominant pond areas with fewer and younger trees (see Figure 2). In such silvofishery systems farmers often do not follow fixed spacing for planting trees along bunds. Commonly planted tree species are coconut and areca nut, which can strengthen embankments while producing fruits. Farmers also plant bitter bean, langsat, and jackfruit as multipurpose tree species around their fishponds.

The gmelina-based agroforestry system, with its stand density of 3794 trees ha ${ }^{-1}$, has a relatively high basal area and $C$ stock at $32.4 \mathrm{~m}^{2} \mathrm{ha}^{-1}$ and $63.7 \mathrm{Mg} \mathrm{ha}^{-1}$, respectively. Some farmers plant gmelina with dense initial spacings of $2 \mathrm{~m} \times 1 \mathrm{~m}$ and/or $2 \mathrm{~m} \times 2 \mathrm{~m}$, and allow several pre-existing tree species (e.g., Swietenia sp., Acacia mangium) to continue growing between the gmelina.

The mixed-tree lot system in the study site shows the highest $C$ stock (i.e., $108.9 \mathrm{Mg} \mathrm{ha}^{-1}$ ), due to the density and variety of trees planted. In this system, farmers also allow natural regeneration of certain shade-tolerant species (e.g., mahogany, large leaf rosemallow) to 
populate empty spaces between the planted trees. The high density of species in this mixed-tree-based system causes high biomass and $C$ stock per unit area. As shown in Figure 3, a simple regression analysis suggests that the BA is a good predictor for $C$ stock value with a coefficient of determination $\left(R^{2}\right)$ value of 0.62 . The $B A$ value describes the accumulation of trees in the stand, which is a function of $\mathrm{D}$ and stand density, although the variables $D$ and stand density themselves cannot be predictor variables for the value of $C$ stock individually.

Table 3. C sequestration capacity of various agroforestry systems in study sites in West Java province.

\begin{tabular}{|c|c|c|c|c|c|c|c|c|c|}
\hline \multirow{2}{*}{$\begin{array}{l}\text { Agroforestry } \\
\text { System }\end{array}$} & \multirow{2}{*}{ Site } & \multicolumn{4}{|c|}{ C Stock (Mg ha $\left.{ }^{-1}\right)$} & \multirow{2}{*}{$\begin{array}{l}\text { Stand Density } \\
\text { (Tree ha }^{-1} \text { ) }\end{array}$} & \multirow{2}{*}{$\begin{array}{l}\text { Diameter } \\
\text { (D) }(\mathrm{cm})\end{array}$} & \multirow{2}{*}{$\begin{array}{l}\text { Tree BA } \\
\left(\mathrm{m}^{2} \mathrm{ha}^{-1}\right)\end{array}$} & \multirow{2}{*}{ Ref } \\
\hline & & Trees & Understory & Necromass & Total & & & & \\
\hline $\begin{array}{l}\text { Manglid + } \\
\text { cardamom }\end{array}$ & Tasikmalaya & $\begin{array}{c}42.3 \\
(14.8-106.2)\end{array}$ & $\begin{array}{c}0.6 \\
(0.1-0.7)\end{array}$ & $\begin{array}{c}1.1 \\
(0.5-2)\end{array}$ & $\begin{array}{c}44 \\
(16.7-108)\end{array}$ & $\begin{array}{c}1247 \\
(500-2250)\end{array}$ & $\begin{array}{c}14.5 \\
(9.3-28.1)\end{array}$ & $\begin{array}{c}20.1 \\
(8.8-41.6)\end{array}$ & {$[42]$} \\
\hline $\begin{array}{l}\text { Gmelina + } \\
\text { cardamom }\end{array}$ & $\begin{array}{l}\text { Tasikmalaya, } \\
\text { Banjar, } \\
\text { Pangandaran }\end{array}$ & $\begin{array}{c}61.7 \\
(19-112.8)\end{array}$ & $\begin{array}{c}0.8 \\
(0.5-1.1)\end{array}$ & $\begin{array}{c}1.4 \\
(0.3-7.7)\end{array}$ & $\begin{array}{c}63.7 \\
(20.3-114.4)\end{array}$ & $\begin{array}{c}3794 \\
(1550-5850)\end{array}$ & $\begin{array}{c}10.1 \\
(5.3-16.3)\end{array}$ & $\begin{array}{c}32.4 \\
(13.2-53.9)\end{array}$ & [43] \\
\hline $\begin{array}{c}\text { Caddam + } \\
\text { Cardamom * }\end{array}$ & Garut & 36.8 & 0.1 & 0.06 & 37.0 & 340.0 & 27.2 & 19.8 & [29] \\
\hline $\begin{array}{l}\text { Caddam + } \\
\text { elephant grass * } \\
\text { Mixed-tree }\end{array}$ & Garut & 36.8 & 0.2 & - & 37.0 & 340.0 & 27.2 & 19.8 & [29] \\
\hline $\begin{array}{l}\text { species and } \\
\text { freshwater } \\
\text { fishpond }\end{array}$ & Ciamis & $\begin{array}{c}53.9 \\
(12.7-89.1)\end{array}$ & 0.1 & ND & $\begin{array}{c}54.0 \\
(12.8-89.2)\end{array}$ & $\begin{array}{c}704.0 \\
(437-1200)\end{array}$ & $\begin{array}{c}15.5 \\
(9.4-18.5)\end{array}$ & $\begin{array}{c}15.7 \\
(14.8-17.5)\end{array}$ & [44] \\
\hline Mixed tree lots & Ciamis & $\begin{array}{c}108.6 \\
(85.9-123.2)\end{array}$ & $\begin{array}{c}0.3 \\
(0.1-0.5)\end{array}$ & ND & $\begin{array}{c}108.9 \\
(86.3-123.4)\end{array}$ & $\begin{array}{c}1633 \\
(1000-2000)\end{array}$ & $\begin{array}{c}11.9 \\
(8.8-17.1)\end{array}$ & $\begin{array}{c}30.2 \\
(24.1-40.6)\end{array}$ & [44] \\
\hline
\end{tabular}

Note: Numbers in parentheses are the range value; $\mathrm{ND}=$ no data; ${ }^{*}$ Data developed from estimation model without range data.
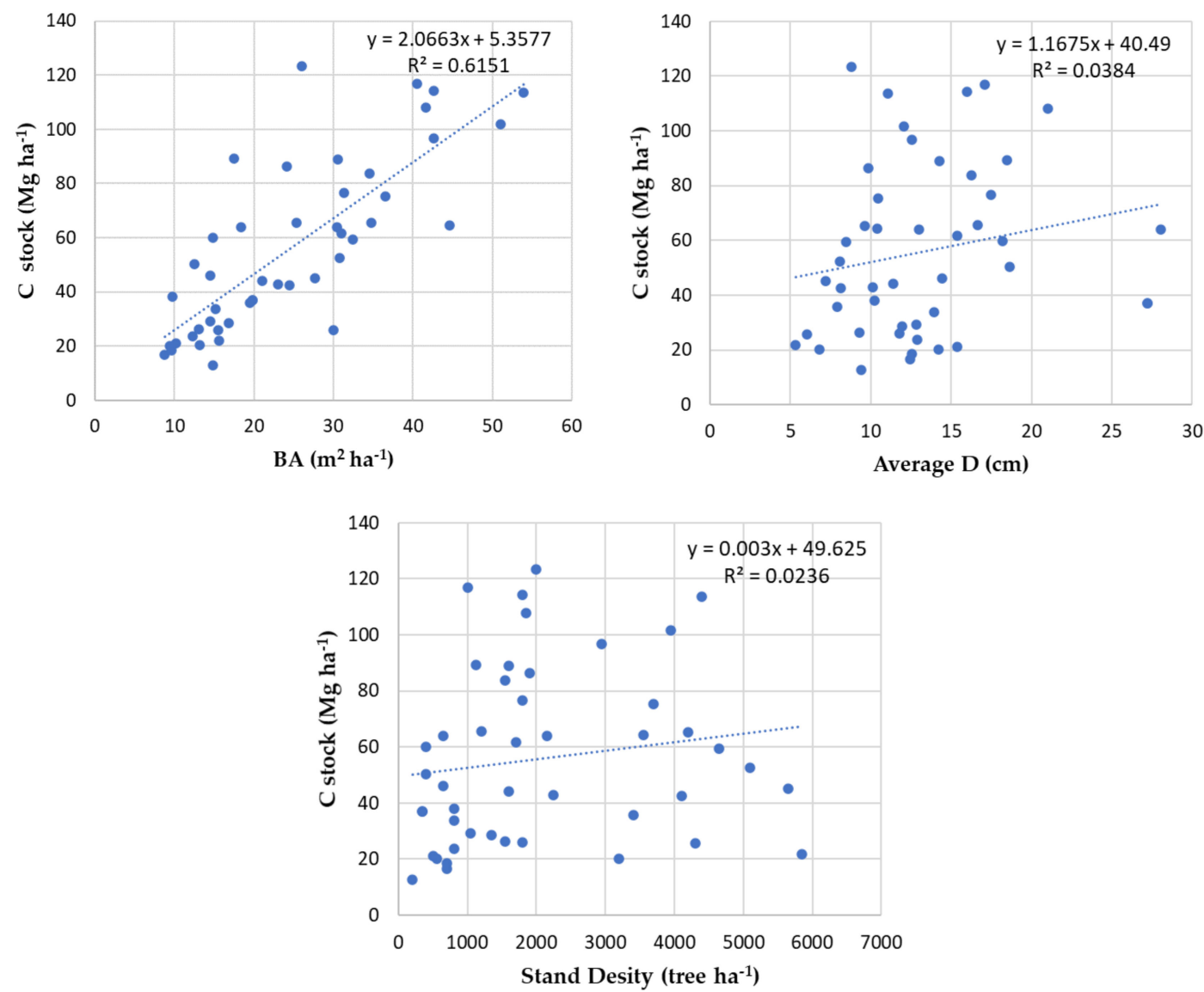

Figure 3. Correlation between $C$ stock and average diameter (D), stand density and basal area (BA) in each measured plots. 


\section{Discussion}

The agroforestry systems observed in the research sites in West Java are crucial for the livelihoods of local farmers, as they have both commercial and subsistence production value. In addition to timber from tree species, cardamom as an understory also has good market prospects, as it is widely used for food flavoring and herbal medicines [54,55]. Cardamom is also a suitable plant for growing under the tree canopy in a low light environment (29\% to $82 \%$ ) [56]. In managing these agroforestry systems, which are less labor-intensive than monoculture agriculture (e.g., rice, corn, beans), farmers mostly use family labor to enhance farm production and profits. However, maximizing the economic benefits of these systems may depend on the availability of labor, land, stable markets, and credit $[57,58]$.

Farmers in the study sites reported that practicing agroforestry helps conserve soil and restore degraded land. Several studies have demonstrated that agroforestry systems can control runoff and soil erosion better than open cropland, thereby reducing losses of water, soil material, organic matter, and nutrients. They can also be employed to reclaim eroded and degraded land [59-61]. Local communities in the Indonesian archipelago possess the knowledge to use many traditional local tree garden-repong damar, simpukng and tembawang agroforestry systems as climate-smart farming, to manage ecosystems and restore degraded land [15]. Considering the high costs involved in land restoration (approximately $260 \mathrm{USD}$ to $2880 \mathrm{USD} \mathrm{ha}^{-1}$, depending on the restoration method used and the condition of land) and global concern for large-scale restoration [27,62,63], involving communities through their agroforestry practices can have low-cost potential (approximately $\$ 181$ US to $\$ 402 \mathrm{US} \mathrm{ha}^{-1}$, see also Rahman et al. [21]). Carbon sequestration across agricultural landscapes is important to minimize net $\mathrm{C}$ emissions from agriculture and mitigate climate change [64]. The agroforestry systems observed in our research sites have stored $37-108.9 \mathrm{MgC} \mathrm{ha}^{-1}$. The carbon stocks of the simple systems (i.e., combination of single trees with cash crop or grass) and mixed-tree system are slightly similar to $C$ stock on agroforestry systems reported by other studies in Indonesia [31,32]. The C stock is found relatively higher in oil palm and agarwood-based systems in Sabah, Malaysia [34]. The mix tree plot systems in our study shows higher potential carbon stock than complex agroforestry system in the buffer zones of a national park in Sulawesi, and mixed tree systems in Bengkulu [33,35]. The variation in C stocks in these systems depends on the amount of biomass in the stands, particularly in tree components. Tree biomass accumulation representing the value of tree BA has a correlation of $C$ stock value (see Figure 3 ). The higher the BA, the higher the biomass accumulation and $C$ stocks. This is what we have found in the mixed-tree lot systems and the gmelina-based agroforestry system (i.e., relatively higher BA and $C$ stock value compared to other three systems of our study).

As the agroforestry systems consisting of various tree species have high $C$ stock potential (see Table 3, mixed tree lots), in order for agricultural land areas to absorb more $\mathrm{C}$, increasing the adoption rate of agroforestry systems consisting of dense mixed tree species is crucial. The accumulation of soil $\mathrm{C}$ also improves soil quality and therefore productivity, and keeping soil in good condition supports farmers in adapting to climate change and extreme weather events [65]. However, targeting to have more $C$ stock by having more trees in the agroforestry systems, farmers may need to compromise understory crop production due to increased tree canopy cover. Therefore, there is a trade-off between number of trees and understory crop production. To maximize overall benefit, farmers may consider planting fast growing timber and/or fruit trees with shade tolerant understory crops, e.g., pineapple (Ananas comosus) and ginger (Zingiber officinale), that also have high market value.

Farmers' adoption of agroforestry can be enhanced through implementation of supportive policies and measures by government and non-government organizations, such as capital support, the establishment of tailored market systems, secured land tenure, and technical assistance [57]. Effective policies should be propagated not by temporary projects but by long-term, government-backed institutions focused on agroforestry practices that 
may need adaptation to meet new opportunities and constraints. Our classification of agroforestry, i.e., agrisilviculture, silvopasture, silvofishery, and mixed tree lots (see Table 2), is based on the structures, components, and management practices of the systems, and this result can contribute to the documentation of agroforestry systems practiced in West Java. As there are gaps in information documenting the multitude of agroforestry systems practiced in different landscapes, such information is crucial for the development of supportive policy frameworks to implement climate smart agroforestry in other parts of Indonesia and elsewhere in the tropics, specifically for benefiting livelihoods and nature through land restoration $[23,57,66]$. The restoration of land using agroforestry can bring win-win solutions in attaining environmental and development objectives, which is also supported by other studies, e.g., degraded land restoration through agroforestry in Wonogiri, Central Java [27], and a burned and degraded peat land restoration project in Pulang Pisau, Central Kalimantan [16].

\section{Conclusions}

This study investigated the $C$ sequestration potential of six agroforestry systems practiced by smallholder farmers in degraded landscapes in West Java province. The mixed-tree system practiced in the Ciamis area was found to have the highest $C$ stock potential, i.e., $108.9 \mathrm{Mg} \mathrm{ha}^{-1}$, while the caddam-based system with cardamom or elephant grass practiced in Garut provides the lowest $\mathrm{C}$ stock $\left(37 \mathrm{Mg} \mathrm{ha}^{-1}\right)$. Tree stand density and diversity are key to having comparatively high or low $C$ stock. Although the observed systems have variations in C stock, they are all crucial for local farmers to prevent topsoil erosion and landslides, and for the restoration of degraded land through tree regeneration. With this empirical evidence, this study contributes to agroforestry system science, specifically in its documentation of the characteristics of systems developed by farmers (i.e., species, structure, products, management) and their capacity for $C$ sequestration, for practicing the restoration of degraded landscapes. However, further studies are required to investigate factors affecting farmers' selection of species, management intensity, market linkages, different landowners' interest in adopting such systems, and testing new systems (considering various fruit, spice, timber, and ornamental trees with various understory crops) targeted at enhancing and diversifying ecological functions in different types of degraded lands in West Java province and elsewhere that could also contribute to climate change mitigation and adaptation.

Author Contributions: Conceptualization, Y.A. and S.A.R.; methodology, M.S., Y.I., M.J.A. and M.L.; software, M.S. and Y.I.; validation, M.S., Y.I., S.A.R., Y.A. and M.L.; formal analysis, M.S. and Y.I.; investigation, M.S. and Y.I.; resources, M.S., S.A.R., Y.I., Y.A. and S.N.; data curation, M.S., S.A.R. and Y.I.; writing —original draft preparation, M.S., S.A.R. and Y.A.; writing—review and editing, S.A.R., Y.A. and M.L.; visualization, Y.I. and S.N.; supervision, Y.A.; funding acquisition, Y.A. All authors have read and agreed to the published version of the manuscript.

Funding: The publication of this research was funded by the National Institute of Forest Science (NIFoS), Republic of Korea.

Data Availability Statement: Data supported the result of this paper can be found by direct request to the authors.

Acknowledgments: The authors would like to thank a number of individuals at the Indonesian Ministry of Environment and Forestry's Research, Development and Innovation Agency (FORDA); CIFOR-ICRAF; and Peking University for their help with the publication. Many thanks are also extended to farmers in the study sites where field surveys were undertaken, who shared their precious time, thoughts and concerns. Our gratitude goes out to the National Institute of Forest Science (NIFoS) in Korea for funding the publication.

Conflicts of Interest: The authors declare no conflict of interest. 


\section{References}

1. Abu Hammad, A.; Tumeizi, A. Land degradation: Socioeconomic and environmental causes and consequences in the eastern Mediterranean. Land Degrad. Dev. 2012, 23, 216-226. [CrossRef]

2. Dubois, O. The State of the World's Land and Water Resources for Food and Agriculture: Managing Systems at Risk; Earthscan: London, UK, 2011; p. 285.

3. Olsson, L.; Barbosa, H.; Bhadwal, S.; Cowie, A.; Delusca, K.; Flores-Renteria, D.; Hermans, K.; Jobbagy, E.; Kurz, W.; Li, D. Land Degradation: IPCC Special Report on Climate Change, Desertification, Land 5 Degradation, Sustainable Land Management, Food Security, and 6 Greenhouse Gas fluxes in Terrestrial Ecosystems; IPCC: Geneva, Switzerland, 2019.

4. Kementerian Lingkungan Hidup dan Kehutanan. Statistik Lingkungan Hidup dan Kehutanan 2018; Kementerian Lingkungan Hidup dan Kehutanan: Jakarta, Indonesia, 2019.

5. MoEF \& UNCCD. Indonesia_Land Degradation Neutrality National Report; Ministry of Environment and Forestry \& UNCCD: Jakarta, Indonesia, 2015.

6. FAO. State of the World's Forests 2016: Forests and Agriculture: Land-Use Challenges and Opportunities; Food Agriculture Organization of the United Nations: Rome, Italy, 2016.

7. Santoro, A.; Venturi, M.; Bertani, R.; Agnoletti, M. A Review of the Role of Forests and Agroforestry Systems in the FAO Globally Important Agricultural Heritage Systems (GIAHS) Programme. Forests 2020, 11. [CrossRef]

8. Baumert, K.A.; Herzog, T.; Pershing, J. Navigating the Numbers: Greenhouse Gas Data and International Climate Policy; World Resources Institute: Washington, DC, USA, 2005.

9. Government of Indonesia. First Nationally Determined Contribution Republic of Indonesia; Government of Indonesia: Jakarta, Indonesia, 2016.

10. Kementerian Lingkungan Hidup dan Kehutanan. Rencana Strategis Direktorat Jenderal Pengendalian DAS and Hutan Lindung Tahun 2020-2024; Kementerian Lingkungan Hidup dan Kehutanan: Jakarta, Indonesia, 2020.

11. Reed, J.; van Vianen, J.; Barlow, J.; Sunderland, T. Have integrated landscape approaches reconciled societal and environmental issues in the tropics? Land Use Policy 2017, 63, 481-492. [CrossRef]

12. ICRAF. Restoring Land with Agroforestry: New Guide Published; ICRAF: Bogor, Indonesia, 2021; Volume 2021.

13. Hillbrand, A. What is the Potential of Agroforestry to Restore Degraded Land in Guatemala? FAO: Rome, Italy, 2021.

14. Rahman, S.A.; Baral, H. Nature-based solution for balancing the food, energy, and environment trilemma: Lessons from Indonesia. In Nature-Based Solutions for Resilient Ecosystems and Societies; Dhyani, S., Gupta, A., Karki, M., Eds.; Springer: Singapore, 2020; pp. 69-82. [CrossRef]

15. Samsudin, Y.B.; Puspitaloka, D.; Rahman, S.A.; Chandran, A.; Baral, H. Community-Based Peat Swamp Restoration Through Agroforestry in Indonesia. In Agroforestry for Degraded Landscapes; Dagar, J.C., Gupta, S.R., Teketay, D., Eds.; Springer: Singapore, 2020; pp. 349-365. [CrossRef]

16. Maimunah, S.; Rahman, S.A.; Samsudin, Y.B.; Artati, Y.; Simamora, T.I.; Andini, S.; Lee, S.M.; Baral, H. Assessment of Suitability of Tree Species for Bioenergy Production on Burned and Degraded Peatlands in Central Kalimantan, Indonesia. Land 2018, 7. [CrossRef]

17. Miccolis, A.; Peneireiro, F.; Marques, H.; Vieira, D.; Arcoverde, M.; Hoffmann, M.; Rehder, T.; Pereira, A. Agroforestry Systems for Ecological Restoration: How to Reconcile Conservation and Production. Options for Brazil's Cerrado and Caatinga Biomes. Instituto Sociedade, População e Natureza-ISPN/World Agroforestry Centre (ICRAF); Instituto Sociedade, População e Natureza: Brasilia, Brazil, 2016.

18. Rahman, S.A.; Sunderland, T.; Kshatriya, M.; Roshetko, J.M.; Pagella, T.; Healey, J.R. Towards productive landscapes: Trade-offs in tree-cover and income across a matrix of smallholder agricultural land-use systems. Land Use Policy 2016, 58, 152-164. [CrossRef]

19. Garrity, D.P. Agroforestry and the achievement of the Millennium Development Goals. Agrofor. Syst. 2004, 61, 5-17. [CrossRef]

20. Garrity, D.P.; Amoroso, V.B.; Koffa, S.; Catacutan, D.; Buenavista, G.; Fay, P.; Dar, W. Landcare on the Poverty-Protection Interface in an Asian Watershed. Conserv. Ecol. 2002, 6, 1-12. [CrossRef]

21. Rahman, S.A.; Jacobsen, J.B.; Healey, J.R.; Roshetko, J.M.; Sunderland, T. Finding alternatives to swidden agriculture: Does agroforestry improve livelihood options and reduce pressure on existing forest? Agrofor. Syst. 2017, 91, 185-199. [CrossRef]

22. Murniati, D.; Garrity, D.P.; Gintings, A.N. The contribution of agroforestry systems to reducing farmers' dependence on the resources of adjacent national parks: A case study from Sumatra, Indonesia. Agrofor. Syst. 2001, 52, 171-184. [CrossRef]

23. Snelder, D.J.; Lasco, R.D. Smallholder Tree Growing for Rural Development and Environmental Services. Lessons from Asia; Springer Science \& Business Media: Berlin, Germany, 2008; Volume 5.

24. Jose, S. Agroforestry for ecosystem services and environmental benefits: An overview. Agrofor. Syst. 2009, 76, 1-10. [CrossRef]

25. Idol, T.; Haggar, J.; Cox, L. Ecosystem Services from Smallholder Forestry and Agroforestry in the Tropics. In Integrating Agriculture, Conservation and Ecotourism: Examples from the Field; Campbell, W.B., Lopez Ortiz, S., Eds.; Springer: Dordrecht, The Netherlands, 2011; pp. 209-270. [CrossRef]

26. Lasco, R.D.; Delfino, R.J.P.; Espaldon, M.L.O. Agroforestry systems: Helping smallholders adapt to climate risks while mitigating climate change. WIREs Clim. Chang. 2014, 5, 825-833. [CrossRef]

27. Rahman, S.A.; Baral, H.; Sharma, R.; Samsudin, Y.B.; Meyer, M.; Lo, M.; Artati, Y.; Simamora, T.I.; Andini, S.; Leksono, B.; et al. Integrating bioenergy and food production on degraded landscapes in Indonesia for improved socioeconomic and environmental outcomes. Food Energy Secur. 2019, 8, e00165. [CrossRef] 
28. Michon, G. Domesticating Forests: How Farmers Manage Forest Resources; CIFOR: West Java, Indonesia, 2005.

29. Indrajaya, Y.; Siarudin, M.; Handayani, W. Karbon tersimpan dalam biomassa agroforestry jabon-kapulaga dan rumput gajah di Kecamatan Pakenjeng, Garut, Jawa Barat. J. Penelit. Agrofor. 2014, 2, 67-74.

30. Takimoto, A.; Nair, P.K.R.; Nair, V.D. Carbon stock and sequestration potential of traditional and improved agroforestry systems in the West African Sahel. Agric. Ecosyst. Environ. 2008, 125, 159-166. [CrossRef]

31. Rahayu, S.; Lusiana, B.; van Noordwijk, M. Above ground carbon stock assessment for various land use systems in Nunukan, East Kalimantan. In Carbon Stock Monitoring in Nunukan, East Kalimantan: A Spatial and Modelling Approach. Report from the Carbon Monitoring Team of the Forest Resource Management for Carbon Sequestration (FORMACS) Project; Lusiana, B., van Noordwijk, M., Rahayu, S., Eds.; World Agroforestry Center: Bogor, Indonesia, 2005; pp. 21-34.

32. Roshetko, J.M.; Delaney, M.; Hairiah, K.; Purnomosidhi, P. Carbon stocks in Indonesian homegarden systems: Can smallholder systems be targeted for increased carbon storage? Am. J. Altern. Agric. 2002, 17, 138-148.

33. Wiryono, W.; Puteri, V.N.U.; Senoaji, G. The diversity of plant species, the types of plant uses and the estimate of carbon stock in agroforestry system in Harapan Makmur Village, Bengkulu, Indonesia. Biodivers. J. Biol. Divers. 2016, 17. [CrossRef]

34. Besar, N.A.; Suardi, H.; Phua, M.-H.; James, D.; Mokhtar, M.B.; Ahmed, M.F. Carbon Stock and Sequestration Potential of an Agroforestry System in Sabah, Malaysia. Forests 2020, 11. [CrossRef]

35. Wardah; Toknok, B.; Zulkhaidah. Carbon stock of agroforestry systems at adjacent buffer zone of Lore Lindu National Park, Central Sulawesi. J. Trop. Soils 2013, 16, 123-128. [CrossRef]

36. Badan Pusat Statistik. Jumlah Penduduk Menurut Kabupaten/Kota (Jiwa) 2020: Badan Pusat Statistik Provinsi Jawa Barat; Badan Pusat Statistik: Jakarta, Indonesia, 2021.

37. Badan Pusat Statistik. Kabupaten Dalam Angka. Available online: https://jabar.bps.go.id/ (accessed on 13 March 2021).

38. Kabupaten Tasikmalaya Dalam Angka. 2021. Available online: https://tasikmalayakab.bps.go.id/publication/2021/02/26/8 8bd050d058c24b3fde94581/kabupaten-tasikmalaya-dalam-angka-2021.html (accessed on 26 February 2021).

39. Kota Banjar Dalam Angka. 2020. Available online: https://banjarkota.bps.go.id/publication/2020/04/27/d433ab1e85911408c2 d935a8/kota-banjar-dalam-angka-2020.html (accessed on 27 April 2020).

40. Kabupaten Pangandaran Dalam Angka. 2020. Available online: https://pangandarankab.bps.go.id/publication/2020/04/27/3 aa1afc640f74adeb926edd7/kabupaten-pangandaran-dalam-angka-2020.html (accessed on 27 April 2020).

41. Nair, P.R. An Introduction to Agroforestry; Springer Science \& Business Media: Berlin, Germany, 1993.

42. Siarudin, M.; Indrajaya, Y. Struktur tegakan dan cadangan karbon hutan rakyat pola agroforestry manglid (Manglieta glauca Bl) di Tasikmalaya, Jawa Barat. J. Penelit. Agrofor. 2014, 2, 45-56.

43. Siarudin, M.; Indrajaya, Y. Dinamika cadangan karbon sistem agroforestri gmelina (gmelina arborea roxb.) pada hutan rakyat di Tasikmalaya Dan Banjar, Jawa Barat. J. Penelit. Agrofor. 2014, 4, 37-46.

44. Siarudin, M. Traditional cropping pattern and management of home garden: Lesson learnt from Ciamis Regency, West Java Province, Indonesia. IOP Conf. Ser. Earth Environ. Sci. 2019, 250. [CrossRef]

45. Hairiah, K.; Dewi, S.; Agus, F.; Velarde, S.; Ekadinata, A.; Rahayu, S.; Van Noodwijk, M. Measuring Carbon Stocks Accross Land Use Systems; ICRAF: Bogor, Indonesia, 2011.

46. Reyes, T.D., Jr.; Ludevese, E.G. Rapid Carbon Stock Appraisal (RACSA) Implementation in Wahig-Inabanga Watershed, Bohol, Philippines. Int. J. Environ. Rural Dev. 2015, 6, 102-109. [CrossRef]

47. Van Noordwijk, M. World Agroforestry Centre (ICRAF) Southeast Asia Program; Rapid Carbon Stock Appraisal (RaCSA): Bogor, Indonesia, 2007.

48. Gusli, S.; Sumeni, S.; Sabodin, R.; Muqfi, I.H.; Nur, M.; Hairiah, K.; Useng, D.; van Noordwijk, M. Soil Organic Matter, Mitigation of and Adaptation to Climate Change in Cocoa-Based Agroforestry Systems. Land 2020, 9, 323. [CrossRef]

49. Chave, J.; Andalo, C.; Brown, S.; Cairns, M.A.; Chambers, J.Q.; Eamus, D.; Fölster, H.; Fromard, F.; Higuchi, N.; Kira, T.; et al. Tree allometry and improved estimation of carbon stocks and balance in tropical forests. Oecologia 2005, 145, 87-99. [CrossRef]

50. Arifanti, V.; Dharmawan, I.; Wicaksono, D. Potensi cadangan karbon tegakan hutan sub montana di Taman Nasional Gunung Halimun Salak. J. Penelit. Sos. Ekon. Kehutan. 2014, 11, 13-31. [CrossRef]

51. Siarudin, M.; Indrajaya, Y. Persamaan allometrik jabon (Neolamarckia cadamba Miq) untuk pendugaan biomassa di atas tanah pada Hutan Rakyat Kecamatan Pakenjeng Kabupaten Garut. J. Penelit. Hutan Tanam. 2014, 11, 1-9. [CrossRef]

52. Zanne, A.E.; Lopez-Gonzalez, G.; Coomes, D.A.; Ilic, J.; Jansen, S.; Lewis, S.L.; Miller, R.B.; Swenson, N.G.; Wiemann, M.C.; Chave, J. Global Wood Density Database. 2009. Available online: https://datadryad.org/stash/dataset/doi:10.5061/dryad.234 (accessed on 30 June 2015).

53. IPCC. IPCC Guideline 2006 Guidelines for National Green House Gas Inventories; IPCC: Geneva, Switzerland, 2006.

54. Ashokkumar, K.; Murugan, M.; Dhanya, M.K.; Warkentin, T.D. Botany, traditional uses, phytochemistry and biological activities of cardamom [Elettaria cardamomum (L.) Maton]—A critical review. J. Ethnopharmacol. 2020, 246. [CrossRef]

55. Wang, X.; Chen, H.; Chang, C.; Jiang, M.; Wang, X.; Xu, L. Study the therapeutic mechanism of Amomum compactum in gentamicin-induced acute kidney injury rat based on a back propagation neural network algorithm. J. Chromatogr. B 2017, 1040, 81-88. [CrossRef] [PubMed]

56. Sudomo, A.; Handayani, W. Karakteristik tanah pada empat jenis tegakan penyusun agroforestry berbasis kapulaga (Amomum compactum Soland ex Maton). J. Penelit. Agrofor. 2013, 1, 1-11. 
57. Rahman, S.A. Incorporation of Trees in Smallholder Land Use Systems: Farm Characteristics, Rates of Return and Policy Issues Influencing Farmer Adoption; Prifysgol Bangor University: Bangor, UK, 2017.

58. Mercer, D.E. Adoption of agroforestry innovations in the tropics: A review. Agrofor. Syst. 2004, 61, 311-328. [CrossRef]

59. Muchane, M.N.; Sileshi, G.W.; Gripenberg, S.; Jonsson, M.; Pumariño, L.; Barrios, E. Agroforestry boosts soil health in the humid and sub-humid tropics: A meta-analysis. Agric. Ecosyst. Environ. 2020, 295. [CrossRef]

60. Wolde, Z. The Role of Agroforestry in Soil and Water Conservation; LAP Lambert Academic Publishing: Sunnyvale, CA, USA, 2015.

61. Kiepe, P.; Rao, M.R. Management of Agroforestry for the Conservation and Utilization of Land and Water Resources. Outlook Agric. 1994, 23, 17-25. [CrossRef]

62. Brown, L.R. Restoring the Earth: The Earth Restoration Budget. Available online: http:/ /www.earth-policy.org/mobile/books/ pb4/PB4ch8_ss7?phpMyAdmin\%20=\%201d6bec-\%201fea35111307d869d19bcd2ce7 (accessed on 20 March 2021).

63. Strassburg, B.B.N.; Latawiec, A.E. The Economics of Restoration: Costs, Benefits, Scale and Spatial Aspects. Available online: https://www.slideshare.net/CIFOR/the-economics-of-restoration-costs-benefits-scale-and-spatial-aspects (accessed on 18 June 2018).

64. Schahczenski, J.; Hill, H. Agriculture, Climate Change and Carbon Sequestration; ATTRA, Ed.; NCAT: Greensboro, NC, USA, 2009.

65. World Bank. Carbon Sequestration in Agricultural Soils; The World Bank: Washington, DC, USA, 2012.

66. Mbow, C.; Van Noordwijk, M.; Luedeling, E.; Neufeldt, H.; Minang, P.A.; Kowero, G. Agroforestry solutions to address food security and climate change challenges in Africa. Curr. Opin. Environ. Sustain. 2014, 6, 61-67. [CrossRef] 